\title{
BACTERIAL DIVERSITY IN SOILS OF DIFFERENT HUNGARIAN KARST AREAS
}

\author{
MÓNIKA KNÁB $^{1,2}$, TIBOR SzILI-KOVÁCs ${ }^{2}$, KÁROLY MÁRIALIGETI ${ }^{1}$, JÁNOS MÓGA ${ }^{3}$ \\ and ANDREA K. BORSODI ${ }^{1}$. \\ ${ }^{1}$ Department of Microbiology, ELTE Eötvös Loránd University, Budapest, Hungary \\ ${ }^{2}$ Centre for Agricultural Research, Institute for Soil Sciences and Agricultural Chemistry, \\ Hungarian Academy of Sciences, Budapest, Hungary \\ ${ }^{3}$ Department of Physical Geography, ELTE Eötvös Loránd University, Budapest, \\ Hungary
}

(Received: 5 June 2017; accepted: 21 November 2017)

Karst areas have great environmental importance as sources of subsurface water and often maintain very sensitive ecosystems. In recent years, increasing number of microbiological studies focused on the bacterial communities of karst soils. In this study, diversity examinations on two distinct Hungarian karst areas, Aggtelek and Tapolca, were performed using parallel cultivation and molecular cloning methods. The phylogenetic affiliation of bacterial strains and molecular clones was determined based on their 16S rRNA gene sequences. Bacterial isolates were identified as members of the phyla Actinobacteria, Firmicutes, Proteobacteria, and Bacteroidetes. Besides the taxa identified by cultivation, members of the phyla Chloroflexi, Cyanobacteria, Acidobacteria, Verrucomicrobia, and Gemmatimonadetes were detected by the cloning. The difference in the composition of soil bacterial communities was related to geographic locations and soil types. Both the highest and the lowest bacterial diversities were detected in samples from Aggtelek National Park, characterized by Leptic Luvisol and Rendzic Leptosol soil types. The difference in the composition of bacterial communities between Rendzic Leptosol and Leptic Phaeozem soil types at Tapolca could be the result of human impacts.

Keywords: bacterial diversity, 16S rRNA gene, karst, cultivation, molecular cloning

\section{Introduction}

Karsts are among the most vulnerable areas and respond very quickly to anthropogenic effects [1]. Recently, increasing number of studies focused on

*Corresponding author; E-mail: borsodi.andrea@ttk.elte.hu 
the soil bacteria inhabiting karst areas. Studying the soil quality changes in the karst area of southwest China, Zhang et al. [2] found that microbial and biological parameters were more sensitive to land degradation or vegetation declining than nutrient pools. Zhou et al. [3] reported on the soil bacterial diversity of a karst forest in China, and presented the first molecular microbiological data in such environment. In another study [4], the interactions among vegetation type, soil physical and chemical conditions, and soil microbial communities in a subtropical karst region were investigated. Chen et al. [5] found that composition and diversity of soil bacterial communities had a complex response to cultivation disturbance in karst ecosystems. $\mathrm{Hu}$ et al. [6] studied how soil microbial indices respond to reforestation, and concluded that soil microbial biomass and activity can be used as early indicators of variation in soil fertility. Zhang et al. [7] investigated the temporal responses of soil prokaryotic communities to clear-cutting disturbance, and demonstrated that bacterial community structure was significantly altered, and it became similar to a reference forest over time.

In Hungary, microbial corrosion capacity of karst soils in Aggtelek National Park (NP) was first analyzed by Zámbó [8], and it was found that soil type had a great impact on it. The soil bacterial communities from two different karst areas of Hungary (Aggtelek and Tapolca) were studied using different cultivationindependent methods [9]. It was found that microbial respiration activity and biomass varied mainly according to soil depths, whereas bacterial community structures revealed by Denaturing Gradient Gel Electrophoresis (DGGE) differed mainly in accordance with geographical location and soil type.

Previously soil bacterial diversity with various vegetation types was studied only by cultivation-based [10-13] or cultivation-independent methods [14-16]. The major limitation of approaches in molecular microbial ecology is the lack of information about the functional and ecological roles of microbial populations. Furthermore, it is asserted that only a minor fraction of soil bacteria can be cultivated. However, despite the inherent known biases of these methods, the different approaches have been rarely used simultaneously to explore the diversity and functional relevance of soil bacterial communities [17-20].

Diversity of soil bacterial communities, inhabiting karst areas has not been studied to date, concurrently using cultivation and cultivation-independent molecular techniques. Therefore, the objective of this study was to improve our knowledge from soil bacterial communities in two distinct karst systems (Aggtelek and Tapolca in Hungary), by revealing community composition and diversity using cultivation and molecular cloning methods, and to compare the results according to geographic location and soil type. 


\section{Materials and Methods}

\section{Study sites and samplings}

The sampling sites for this study are situated on Tapolca- and Aggtelek-karst (Table I). The area of Aggtelek-karst (NE Hungary) belongs to the Aggtelek NP. Its underground caves together with the Slovak Karst caves were put on the UNESCO World Heritage List in 1995. It is a hilly terrain mainly forested karst area. Tapolca-karst is in W Hungary, probably the most vulnerable Hungarian karst system, a mosaic of partly open and covered karst areas (covered by forests and grasslands). Its surface and underground karst features are not as prominent as in Aggtelek-karst, and previously significant bauxite mining had been conducted here. The climate of Aggtelek is cooler and wetter than Tapolca; the mean annual temperature and precipitation values are $8-9{ }^{\circ} \mathrm{C}$ and $1,200-1,300 \mathrm{~mm}$ versus $11-12{ }^{\circ} \mathrm{C}$ and $800-900 \mathrm{~mm}$, respectively.

Within both karst areas, two sampling sites were selected (Table I). Both Aggtelek sampling sites (AR and VC) were located on hill plateau. The location of both Tapolca sampling sites (TR and TW) was also in plateau. The common feature of soils at four sampling sites is a relatively shallow " $\mathrm{A}$ " horizon, which is directly connected to the "C" bedrock horizon, all belongs to the rendzina soil type according to the Hungarian Soil Classification System. The AR site is located near Aggtelek village at a karst plateau covered by forest, the thickness of the humus layer was $15 \mathrm{~cm}$, the soil type was black rendzina (Rendzic Leptosol in WRB), and texture is silty clay. The VC site is located near Jósvafó village at a karst plateau of the Vörös doline covered by grassland, the thickness of the humus layer was $30 \mathrm{~cm}$, the soil type was red clay rendzina [Leptic Luvisol (clayic and chromic) in WRB], and the texture is clay. The TR site is located at the plateau of the Alsó-Cser-tó covered by grassland, the thickness of the humus layer is $25 \mathrm{~cm}$, the soil type is black rendzina (Rendzic Leptosol in WRB), and texture is clay loam mixed with small to large limestone particles. The TW site is located near the roadside entering Zalahaláp village at a plateau used for pasture and for illegal waste deposition, the vegetation is degraded grassland with bare soil spots, the thickness of the humus layer is $15 \mathrm{~cm}$, the soil type is brown rendzina (Leptic Phaeozem in WRB), and texture is sandy loam.

In each site, a representative plot was appointed and three individual soil cores from the surface $(0-15 \mathrm{~cm})$ were randomly taken and pooled at each plot. Approximately, $500 \mathrm{~g}$ of each soil sample was collected into sterile bottles and transported in cooling box to the laboratory. Before analyses, soil samples were thoroughly mixed, the visible roots and other plant residues were carefully removed and sieved ( $2 \mathrm{~mm}$ mesh) using sterile instruments. 


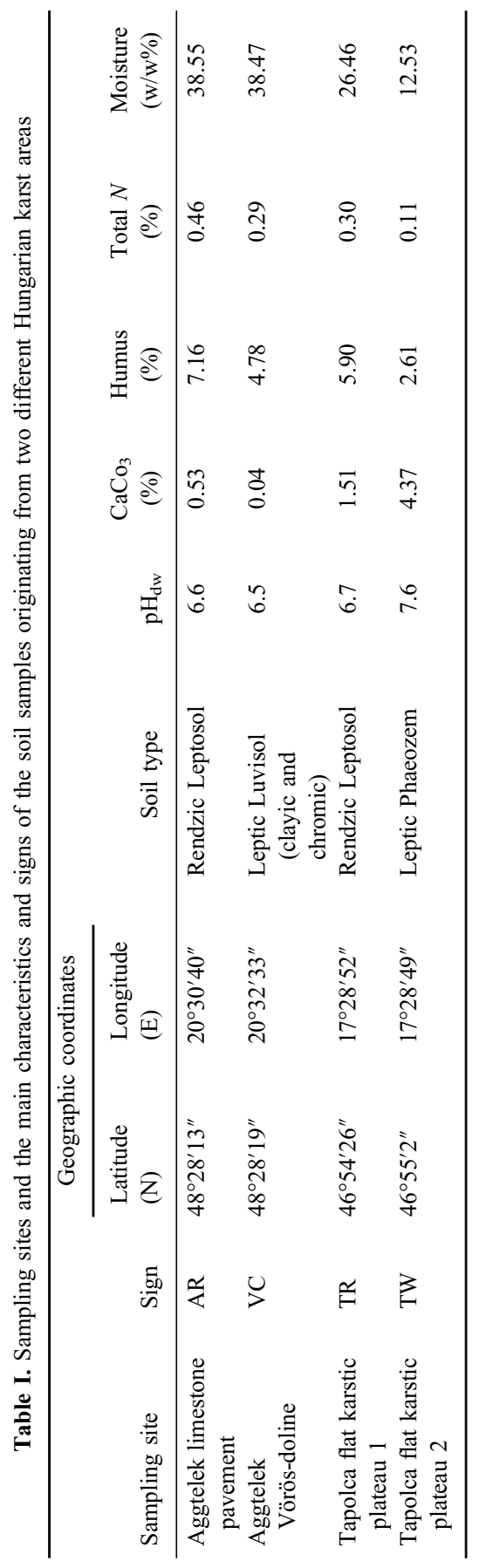


The measured physical and chemical characteristics of the soil samples are shown in Table I.

Soil $\mathrm{pH}$ was measured using a $\mathrm{pH}$ meter from soil suspensions (1:2.5 soil to distilled water weight ratio), gravimetric soil water content was determined from $15 \mathrm{~g}$ soil oven-dried at $105^{\circ} \mathrm{C}$, lime content $\left(\mathrm{CaCO}_{3}\right)$ was measured by Scheibler calcimeter, humus content was measured by wet oxidization of soil organic matter by potassium dichromate $\left(\mathrm{K}_{2} \mathrm{Cr}_{2} \mathrm{O}_{7}\right)$ in the presence of sulfuric acid $\left(\mathrm{H}_{2} \mathrm{SO}_{4}\right)$ according to Tyurin method, total $N$ was measured by Kjeldahl method. Soil textures were identified after determining the proportion of sand, silt, and clay particles by pipetting method and classified by the soil texture triangle.

\section{Cultivation of bacterial strains, DNA isolation, and PCR amplification}

Tenfold serial dilutions were made from the soil samples using sterile water. The following media were chosen for plating: (1) nutrient (DSMZ Medium 1, www. dsmz.de); (2) R2A (DSMZ Medium 830, www.dsmz.de); and (3) starch-casein agar [21]. After 10 days of incubation at $28^{\circ} \mathrm{C}$, colony forming unit (CFU) numbers were determined, and bacterial colonies with different morphology were isolated. Bacterial strains were maintained on the isolation media.

DNA isolation from the pure cultures was made by bead-beating technique of physical fractioning. The bacterial biomass derived from $24 \mathrm{~h}$ cultures was suspended in $100 \mu$ sterile diethyl pyrocarbonate-treated water and a spatula of sterile glass beads was added, then the cells were disrupted with a Mixer Mill MM301 (Retsch, Haan, Germany). After centrifugation (1 min, 13,000 × g), DNA was denaturized for $5 \mathrm{~min}$ at $99{ }^{\circ} \mathrm{C}$ in a 2720 Thermal Cycler (Applied Biosystems, Carlsbad, CA, USA). Following a repeated centrifugation (3 min, $13,000 \times g$ ), samples were stored at $-22^{\circ} \mathrm{C}$. Presence of the DNA was detected in $1 \%$ agarose gel stained with ethidium bromide, and visualized with UV excitation after running $20 \mathrm{~min}$ on $100 \mathrm{~V}$.

The 16S rRNA of bacterial strains was amplified by PCR using 27f [22] and 1401r [23] primers, in a 2720 Thermal Cycler, with the following temperature protocol: initial denaturation at $95{ }^{\circ} \mathrm{C}$ for $3 \mathrm{~min}$, followed by 32 amplification cycles of $30 \mathrm{~s}$ at $94{ }^{\circ} \mathrm{C}, 30 \mathrm{~s}$ at $52{ }^{\circ} \mathrm{C}$, and $1 \mathrm{~min}$ at $72{ }^{\circ} \mathrm{C}$, followed by final extension at $72{ }^{\circ} \mathrm{C}$ for $30 \mathrm{~min}$. The PCR reaction mixture contained $0.2 \mathrm{mM}$ of each deoxynucleoside triphosphate, $1 \mathrm{U}$ of LC Taq DNA Polymerase (recombinant) (Fermentas, Vilnius, Lithuania), $1 \times$ Taq buffer with $\left(\mathrm{NH}_{4}\right)_{2} \mathrm{SO}_{4}$ (Fermentas, Vilnius, Lithuania), $2 \mathrm{mM} \mathrm{MgCl}_{2}, 0.65 \mathrm{mM}$ of each primer, and about $20 \mathrm{ng}$ of genomic DNA template in a total volume of $50 \mu \mathrm{l}$. Presence and quality of PCR products was checked by agarose gel electrophoresis, following the method described above. 


\section{Clone library construction}

Prior to cloning, total community DNA was extracted from $1.0 \mathrm{~g}$ of each soil sample using Ultra Clean Soil DNA Isolation Kit (Mo-Bio, Carlsbad, CA), according to the manufacturer's instructions. The 16S rRNA fragments of the whole community DNA were amplified using $27 \mathrm{f}$ and $1401 \mathrm{r}$ primers, as described above. PCR products were purified using EZ-10 Spin Column PCR Products Purification Kit (Bio Basic Canada Inc., Canada) following the manufacturer's instructions.

Clone libraries were constructed based on blue-white selection method [24]. The purified PCR products were ligated into TA-cloning vectors (pGEM-T Vector System, Promega, USA) than transformed into competent Escherichia coli JM109 cells. To retrieve the insert sequence from recombinant plasmids, two PCRs were run. First, clones were amplified with vector specific M13 (5'-GTAAAACGACGGCCAG-3') forward and (5'-CAGGAAACAGCTATGAC-3') reverse primers (Integrated DNA Technologies, USA) followed by a nested PCR with the original primers to obtain the original inserts without the vector's flanking regions. Reactions were run as previously described.

\section{Identification of bacterial strains and molecular clones}

The PCR products of bacterial strains and molecular clones were grouped by amplified ribosomal DNA restriction analysis (ARDRA) using enzymes of MspI and $B s u$ RI (Fermentas, Vilnius, Lithuania) as described by Massol-Deya et al. [25]. Digestion products were separated in 2\% ethidium bromide-stained agarose gel (Gibco, CA, USA), visualized by UV excitation using Micromax CCD camera, and analyzed by image analyzer software (Princetone Instruments, USA). PCR products of representative strains and molecular clones with unique restriction patterns were purified with EZ-10 Spin Column PCR Products Purification Kit (Bio Basic Canada Inc.).

Identification was based on the partial sequence analysis of 16S rRNA gene using 27f primer and Big Dye Terminator Ready Cycle Sequencing Kit (Applied Biosystems, Carlsbad, California), as recommended by the manufacturer. Following ethanol precipitation, our own sequencing facility, an ABI PRISM 310 Genetic Analyzer (Applied Biosystems) was applied to obtain sequences of approximately $570 \mathrm{bp}$ in the hypervariable (V3) region of the $16 \mathrm{~S}$ rRNA gene. Ambiguous sequences were discarded and chimera sequences were also excluded from further analysis. Chromatograms were manually checked using the Chromas software (Technelysium Pty Ltd., Tewantin, Australia). Taxonomic relationships 
of the sequences were determined by Basic Local Alignment Search Tool algorithm [26] in the GenBank online database (http://www.ncbi.nlm.nih.gov) and using the EzTaxon server [27] based on 16S rRNA gene sequence data. Phylogenetic and molecular evolutionary analyses were performed using MEGA version 5.0 [28] (neighbor-joining method, Kimura 2-P nucleotide substitution model).

The partial sequences of the bacterial strains and molecular clones deposited in the GenBank have accession numbers between HE681124-HE681224 and HE663609-HE663760, respectively.

\section{Calculation of the diversity index}

Bacterial diversity was calculated using the Shannon-Weaver index $\left(\mathrm{H}^{\prime}\right)[29]$.

$$
\mathrm{H}^{\prime}=-\Sigma p i \ln p i,
$$

where $p i$ is the relative abundance of the $i$ th operational taxonomic unit (OTU). To calculate the phylogenetic diversity index, the bacterial phyla were considered for OTU-s in case of both the cultivation and the clone library analysis.

\section{Statistical analysis}

Principal component analysis (PCA) using Past Paleontological Statistics V2.08 program [30] was performed.

\section{Results}

\section{Bacterial colony forming unit numbers}

For the enumeration of bacteria, three media with different composition were chosen (Table II). In the soil samples, an average of $7.8 \times 10^{6} \mathrm{CFU} / \mathrm{g}$ value was counted, and the difference among the $\mathrm{CFU}$ values was less than one order of magnitude. The highest CFU numbers were determined in the AR, whereas the lowest in the TR samples. Regarding the media used, the higher CFU numbers were detected on the R2A medium, containing the lowest organic matter concentration, in agreement with the observations of Van Insberghe et al. [20], notably that the efficiency of recovering abundant community members through cultivation increases as the incubation conditions decrease in nutrient availability and favor slower growth. 
Table II. Bacterial count (CFU/g) values of the soil samples from Hungarian karst areas

\begin{tabular}{lccc}
\hline & \multicolumn{3}{c}{ CFU numbers on different media } \\
\cline { 2 - 4 } Soil sample & Nutrient & R2A & Starch-casein \\
\hline AR & $9.1 \times 10^{6}$ & $1.6 \times 10^{7}$ & $9.4 \times 10^{6}$ \\
VC & $8.1 \times 10^{6}$ & $1.3 \times 10^{7}$ & $2.0 \times 10^{7}$ \\
TR & $4.1 \times 10^{6}$ & $6.0 \times 10^{6}$ & $4.7 \times 10^{6}$ \\
TW & $9.0 \times 10^{6}$ & $7.2 \times 10^{6}$ & $5.5 \times 10^{6}$ \\
\hline
\end{tabular}

Note: For abbreviations see Table I.

\section{Diversity of bacterial strains}

From a total of 192 bacterial strains (ARS: 50, VCS: 48, TRS: 53, TWS: 41), 101 ARDRA representatives (ARS: 19, VCS: 26, TRS: 25, TWS: 31) were selected, which belonged to 38 genera of 4 bacterial phyla. In both Aggtelek NP samples (AR and VC), representatives of the phylum Actinobacteria (40\% and 43\%), while in the Rendzic Leptosol sample from Tapolca (TR) Proteobacteria $(51 \%)$ were present in the largest amount (Figure 1). In the Tapolca sample located near the waste depository (TW), Actinobacteria and Proteobacteria occurred in equal ratios (44\%-44\%). Members of the phylum Firmicutes were also found in high numbers in the Rendzic Leptosol samples (AR 35\% and TR 25\%). The ratio of bacterial strains belonging to Bacteroidetes ranged between $5 \%$ and $10 \%$ in each sample.

At the genus level, the proportion of the isolated strains were: Bacillus (18\%), Pseudomonas (14\%), and Streptomyces (14\%), while strains from other genera were represented only $5 \%$ or below. The highest species diversity was revealed in the waste contaminated sample from Tapolca (TW), whereas the lowest was revealed in the Rendzic Leptosol sample from the Aggtelek NP (AR) with 26 and 18 different taxa, respectively. Despite that similar number of taxa was identified from the samples, the revealed composition was greatly different. Only representatives of the genera Streptomyces (Actinobacteria), Bacillus (Firmicutes), Pseudomonas (Gammaproteobacteria), and Flavobacterium (Bacteroidetes) were isolated from each sample (Figures 2 and 3). Members of the genera Microbacterium, Leifsonia, Kribbella, and Solitalea were represented by isolates only from both Aggtelek, whereas Micrococcus, Paenisporosarcina, Sphingomonas, and Lysobacter were represented only from both Tapolca samples. The genera Rhodococcus, Amycolatopsis, Lentzea, Aeromicrobium, Cohnella, Mesorhizobium, Rhizobium, Paracoccus, Achromobacter, Duganella, Mitsuaria, Xenophilus, Pseudoxanthomonas, Xanthomonas, and Thermomonas, several of 


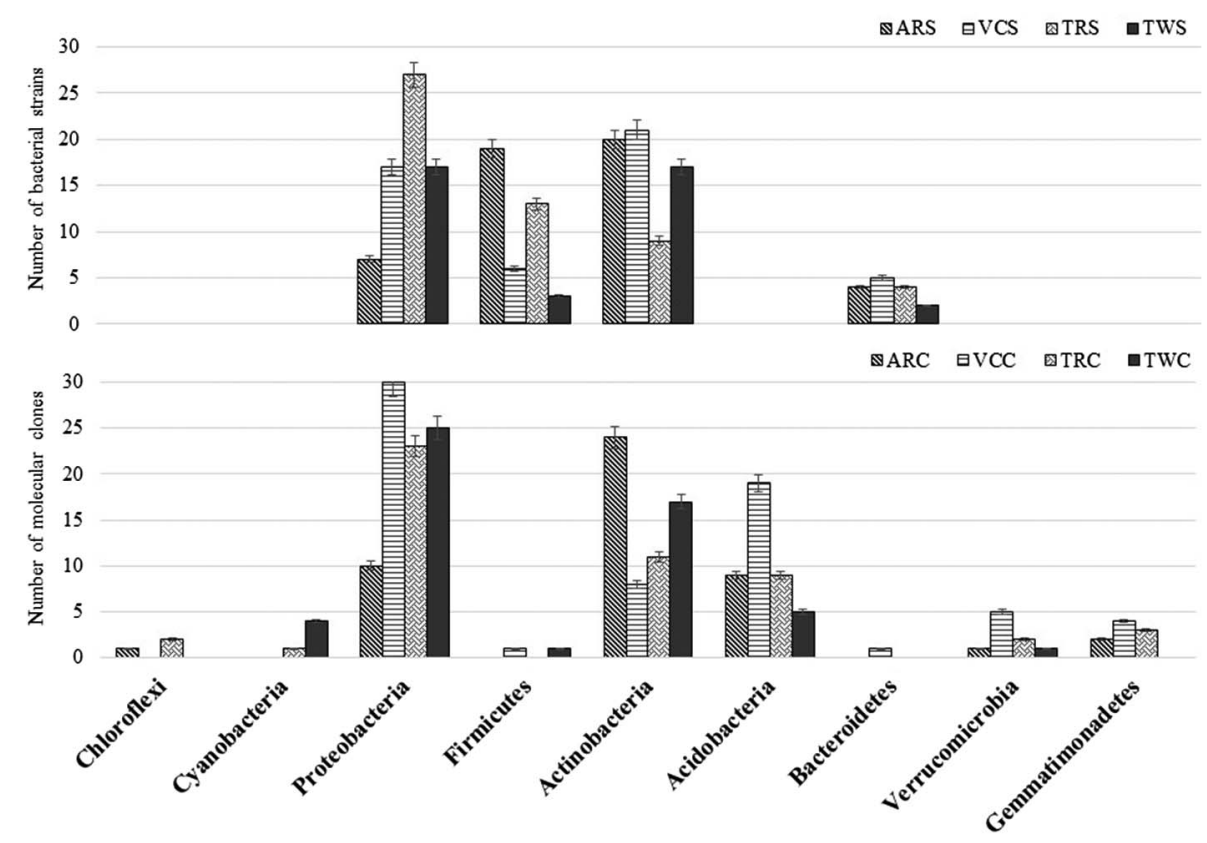

Figure 1. Phylogenetic distribution of bacterial strains and molecular clones from the soil samples of two different Hungarian karst areas. AR: Aggtelek limestone pavement sample; VC: Aggtelek Vörös-doline; TR: Tapolca flat karstic plateau 1; TW: Tapolca flat karstic plateau 2; S: bacterial strains; C: molecular clones

them described in recent years from various soil and rhizosphere samples, were represented by single isolates both in the Aggtelek and Tapolca samples (Figures 2 and 3). The $16 \mathrm{~S}$ rRNA gene sequence analysis showed that 77 out of the 101 representative strains had $98 \%-100 \%$ similarity values to validly described species (Figures 2 and 3).

\section{Distribution of bacterial clones}

During the molecular cloning, sequence analysis of the 152 ARDRA representatives (ARC: 33, VCC: 39, TRC: 42, TWC: 38) was performed from a total of 219 clones (ARC: 47, VCC: 68, TRC: 51, TWC: 53). In all clone libraries representatives of the phyla Proteobacteria, Actinobacteria and Acidobacteria were detected in the highest proportion (Figure 1). Proteobacteria were the most abundant group in both sites of Tapolca karst and in the Leptic Luvisol (clayic) sample from Aggtelek NP (VC), whereas in the Rendzic Leptosol sample from Aggtelek NP (AR), members of the phylum Actinobacteria were detected in the 


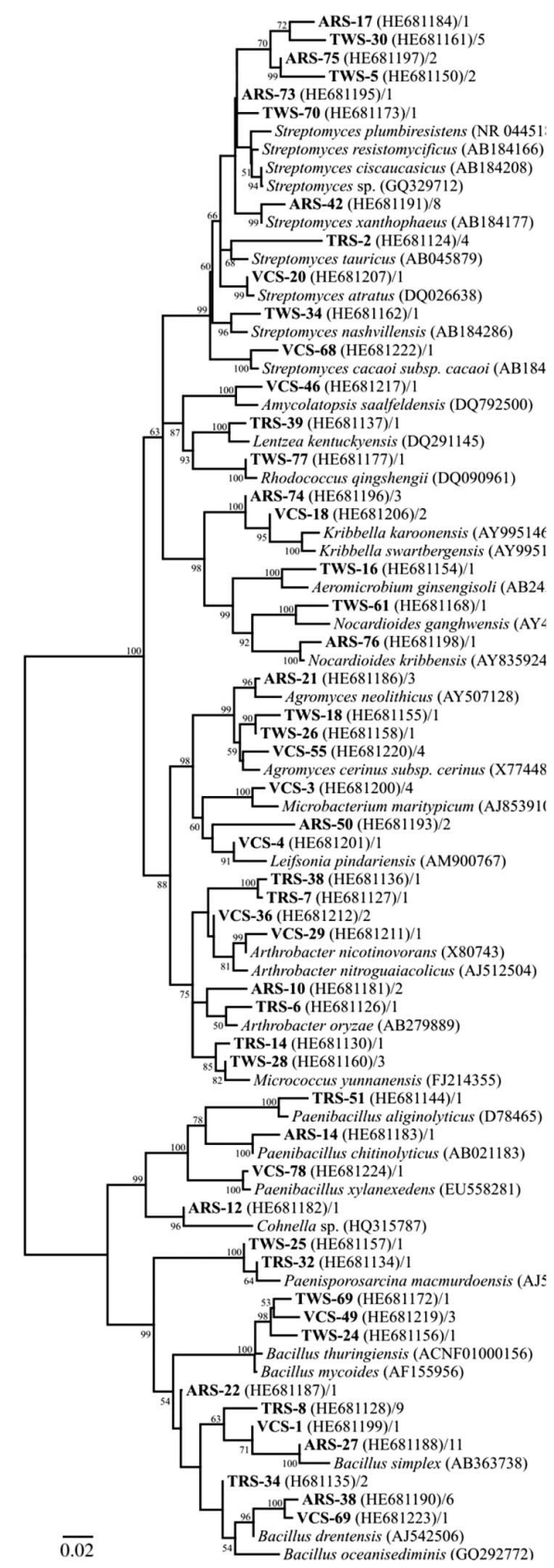

Figure 2. 16S rDNA sequence-based neighbor-joining phylogenetic tree of bacterial strains belonging to the Actinobacteria and Firmicutes phyla. (Bacterial strains from the soil samples isolated from the Hungarian karst areas appear in bold. Only bootstrap values above $50 \%$ are shown.

Bar, 2 substitutions per 100 nucleotide positions.) 


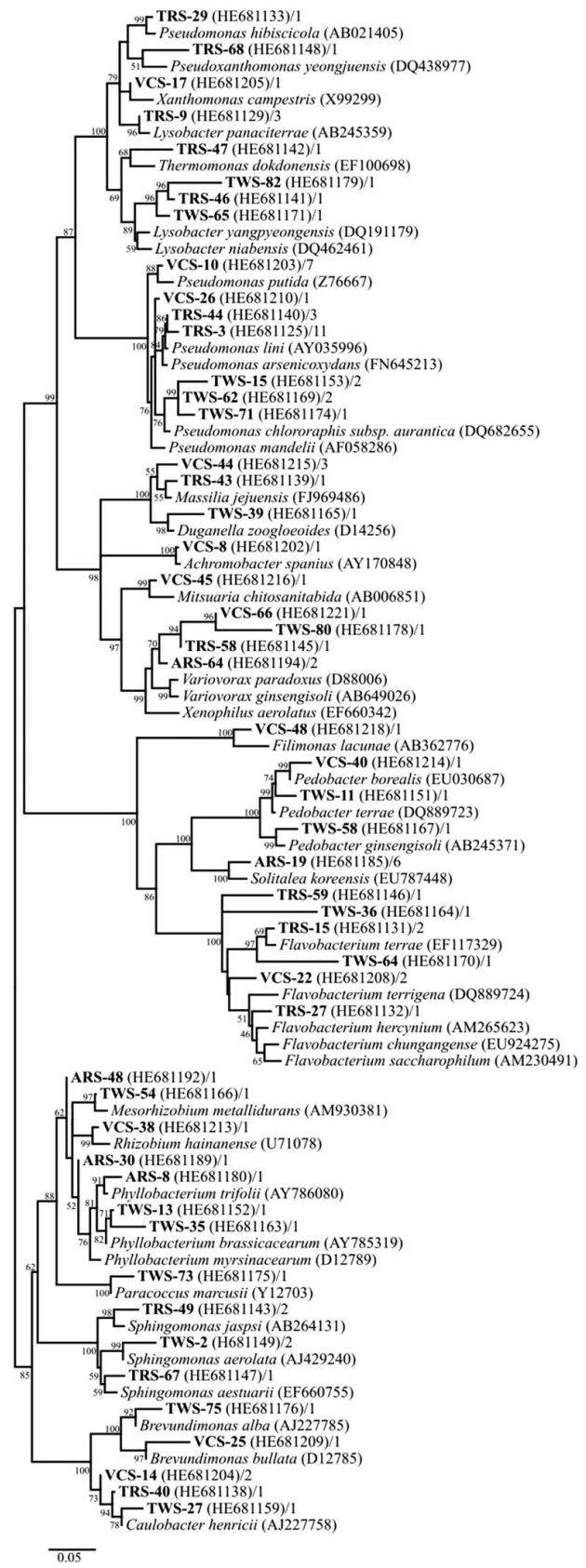

Figure 3. 16S rDNA sequence based neighbor-joining phylogenetic tree of bacterial strains belonging to the Proteobacteria and Bacteroidetes phyla. (Bacterial strains from the soil samples isolated from the Hungarian karst areas appear in bold. Only bootstrap values above $50 \%$ are shown. Bar, 2 substitutions per 100 nucleotide positions.) 
largest proportion. Considering the clone sequences, altogether 58\% of them belonged to one of the four phyla revealed by cultivation. Others were representatives of the class Deltaproteobacteria and the phyla Acidobacteria, Gemmatimonadetes, Verrucomicrobia, Chloroflexi, and Cyanobacteria, detected only by molecular cloning.

In all four clone libraries, Acidobacteria occurred in relatively high, whereas Verrucomicrobia in low proportions (Figure 1). Sequences belonging to the phylum Chloroflexi were found in the clone libraries deriving from Rendzic Leptosol soil samples in both karst areas (AR and TR). Cyanobacteria-related sequences were found only in the soil samples from Tapolca karst. In addition, clone sequences related to the phylum Gemmatimonadetes were not found in the soil sample from the nearby of the waste depository in Tapolca karst (TW).

In most cases, the sequence similarities of the molecular clones to the described bacterial species were below 97\%; therefore, these sequence data can be interpreted only at higher taxonomic levels.

\section{Diversity calculations}

According to the Shannon-Weaver diversity indices calculated for the individual soil samples, higher diversity values were obtained using clone library analysis than cultivation (Table III). Either via cultivation or molecular cloning, no significant difference was observed in the bacterial diversity of the studied samples. The lowest soil bacterial diversity was found in the Rendzic Leptosol sample from Aggtelek (AR) with both methods. Calculating these indices for the two karst areas, it was found that bacterial diversity of soil samples from Aggtelek was slightly lower than that of Tapolca karst based on both methods (Table III).

\section{Discussion}

In all clone libraries, representatives of phyla Proteobacteria, Actinobacteria, and Acidobacteria were detected in the highest proportion, which agrees with other studies [15, 31-33], showing that these are the most abundant phyla in different soils. The prominence of phyla Acidobacteria and Proteobacteria could be explained by their well-known adaptation to slightly acidic and low-nutrient environments [34]. According to the results of the NCBI database, the vast majority of the clone sequences showed the highest sequence similarity (between 94\% and 99\%) to uncultured environmental clone sequences. Many environmental clones originated from soils, mainly the rhizosphere of 
Table III. Shannon-Weaver diversity indices $\left(\mathrm{H}^{\prime}\right)$ calculated for (1) bacterial communities of the individual soil samples revealed by cultivation or cloning; (2) bacterial communities of the two karst areas revealed by cultivation or cloning; and (3) all the identified bacteria via cultivation or cloning

\begin{tabular}{|c|c|c|c|c|c|}
\hline 1 & $\mathrm{H}^{\prime}$ & 2 & $\mathrm{H}^{\prime}$ & 3 & $\mathrm{H}^{\prime}$ \\
\hline ARS & 1.34 & $\begin{array}{l}\text { Strains of Aggtelek } \\
(\text { ARS + VCS })\end{array}$ & 1.55 & $\begin{array}{l}\text { All strains } \\
(\text { ARS + VCS + TRS + TWS })\end{array}$ & 1.63 \\
\hline VCS & 1.59 & & 1.9 & & \\
\hline ARC & 1.49 & $\begin{array}{l}\text { Clones of Aggtelek } \\
(\text { ARC + VCC })\end{array}$ & 1.9 & & \\
\hline VCC & 1.96 & & & & \\
\hline TRS & 1.53 & $\begin{array}{l}\text { Strains of Tapolca } \\
\text { (TRS + TWS })\end{array}$ & 1.62 & $\begin{array}{l}\text { All clones } \\
(\mathrm{ARC}+\mathrm{VCC}+\mathrm{TRC}+\mathrm{TWC})\end{array}$ & 2.05 \\
\hline TWS & 1.55 & & & & \\
\hline TRC & 2.04 & $\begin{array}{l}\text { Clones of Tapolca } \\
(\text { TRC + TWC) }\end{array}$ & 2.08 & & \\
\hline TWC & 1.89 & & & & \\
\hline
\end{tabular}

plants [35-38], but other sequences were obtained from waste sites, microbial mats, animal faeces, and in the case of nitrogen fixing bacterial species, in the nodules of the host species [39-42].

In the soils of karst forests, Proteobacteria, Acidobacteria, and Actinobacteria were described as dominant members of bacterial communities $[3,5,7]$. Proteobacteria and Actinobacteria were the most abundant phyla by both methods in this study as well. Furthermore, high proportion of phyla Firmicutes and Acidobacteria were also detected by cultivation or molecular cloning. The difference between the results obtained by the two methods can be explained by their known selectivity [43]. While the used cultivation was suitable for the detection of mainly aerobic, chemoorganoheterotrophic bacteria, the use of molecular cloning made possible to reveal bacteria difficult to cultivate or with different (e.g., obligate anaerobic) metabolism. Recently, high-throughput sequencing approaches make it possible to investigate microbial communities with far greater sample numbers and phylogenetic resolution [15] than with those methods, which were available for us during this study. However, Van Insberghe et al. [20] showed that standard media and conventional cultivation techniques have the potential to isolate abundant members of forest soil bacterial communities, as evaluated and previously characterized by pyrotag sequencing [16]. Moreover, such a strain collection could be representative for the bacterial diversity present in the soil environment [34].

Representatives of the phylum Proteobacteria were the most abundant in all samples except for the Rendzic Leptosol sample from Aggtelek (AR) (Figure 1). Proteobacteria not only form a physiologically diverse group, with many fast-growing r-strategists that can colonize plant roots and can be abundant in 
various soils [44], but also K-strategists such as several members of the Alphaproteobacteria [45]. In this study, members of the classes Alpha-, Beta-, and Gammaproteobacteria were detected in large numbers by both methods, however, sequences related to the class Deltaproteobacteria could only be revealed by molecular cloning. The distribution of sequences between the classes of Proteobacteria was quite different according to samples as Alpha-, Beta-, and Deltaproteobacteria were characteristic to Leptic Luvisol (clayic) sample from Aggtelek (VC), whereas Gammaproteobacteria to soil samples from Tapolca karst. Members of the genera Rhizobium, Mesorhizobium, and Variovorax were detected by both methods, but Pseudomonas proved to be the most frequent among the bacterial strains (Figure 3). The fact that samples from Tapolca karst were characterized by a high proportion of Gammaproteobacteria (Figure 4), may be related to the so called "gamma shift" phenomenon, observed by Militon et al. [41] studying the bacterial community composition during the aerobic bioremediation of an aliphatic hydrocarbon-contaminated industrial area. The hydrocarboncontaminated soils were characterized by a higher proportion of Gammaproteobacteria, similar to that found in the Tapolca karst where signs of strong human impact (illegal waste disposal) could be observed. From the TW sample (Tapolca karst), several isolates were identified as species (e.g., Mesorhizobium metallidurans, Rhodococcus quingshengii, Streptomyces plumbiresistens, and Variovorax paradoxus) that have been described to tolerate the presence of heavy metals, synthetic contaminants, and even degrade the latter.

Actinobacteria were also abundant in the soil samples from both studied Hungarian karst areas (Figure 2), as also found by Baldrian et al. [15], characterizing the total bacterial and fungal communities of Picea abies forest using DNA and RNA sequencing. Several bacterial strains isolated from the Aggtelek and Tapolca karst samples were identified as different Streptomyces species (Figure 2), known as antibiotic producers (e.g., Streptomyces resistomycificus and Streptomyces atratus) [46, 47] or used in biotechnology (e.g., Streptomyces ciscaucasicus) [48]. It is noteworthy that all strains identified as $S$. plumbiresistens, a heavy metal-resistant actinobacterium described from a lead-polluted soil in China [49], were isolated only from the Tapolca karst sample (TW) located near a waste depository. The species Rhodococcus qingshengii described from a carbendazim-contaminated soil sample in China [50] was also detected only from the waste-polluted Tapolca soil sample (TW). However, most AR strains originated from the partly covered Aggtelek karst were identified as Streptomyces xanthophaeus, which was revealed from the Spanish karst caves as well [51]. Some other AR strains showed the highest sequence similar to the type strain of Agromyces neolithicus, described from a soil sample of a relatively unexplored hypogenic environment [52]. 


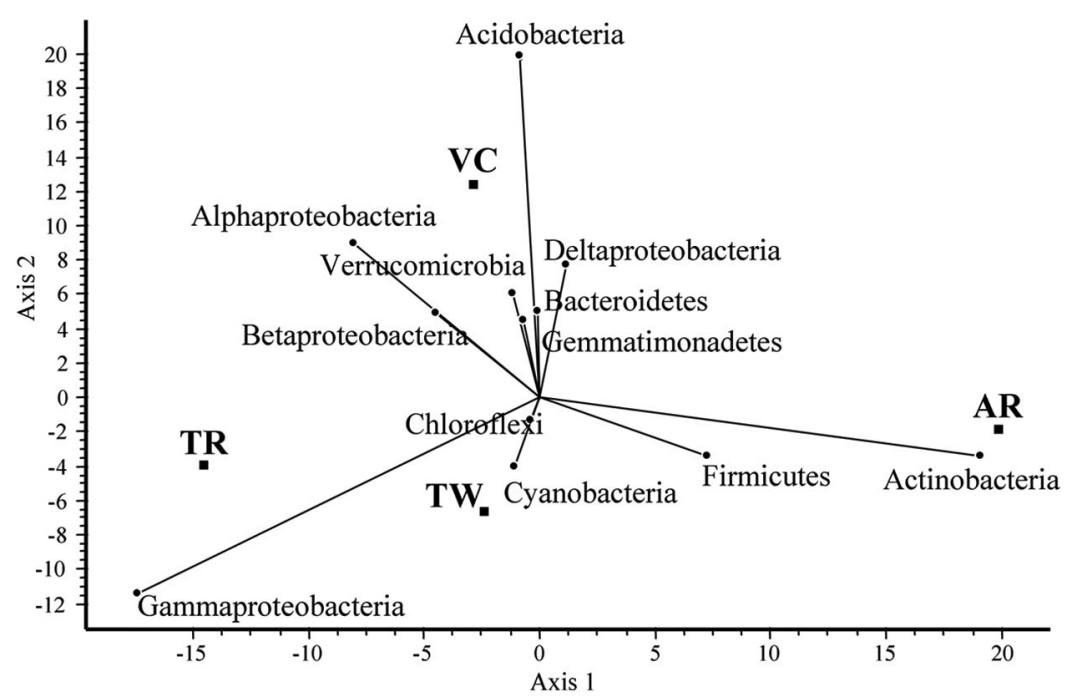

Figure 4. Two-dimensional principal components biplot describing the phylogenetic variability of soil bacterial communities from different Hungarian karst areas (for abbreviations, see Table I)

On the whole, the distribution of bacterial strains and molecular clones and the composition of soil bacterial communities of the studied karst soils seem to be influenced by geographic localization and soil type, although we did not examine the effects of soil factors on bacterial composition along a chronosequence, as it has been done, e.g., by Zhang et al. [7]. According to the PCA biplot (Figure 4), samples from the Tapolca karst showed greater similarities to each other than samples from Aggtelek NP. Along Axis 1, the Rendzic Leptosol soil sample from Aggtelek (AR) dominated by Gram-positive bacteria (Actinobacteria and Firmicutes) clearly separated from the other three samples, characterized by the dominance of Gram-negative bacteria (mainly Proteobacteria). The Rendzic Leptosol soil located on a limestone hill-side in Aggtelek could be characterized by very shallow soil layer (max. $15 \mathrm{~cm}$ ), sparse vegetation, the highest humus, total N, and moisture content (Table I). The extreme temperature and soil water balance values developing in this area (AR) may favor the high proportion of xerotolerant Actinobacteria. Leptic Luvisol (clayic) sample (VC) separated from the others according to the 2nd axis of the PCA biplot (Figure 4), which related to its Acidobacteria dominance. Acidobacteria are frequently detected in clone libraries from different soil samples, and are thought to be of great ecological significance, but only a few species could have been cultivated [34]. The strains of Acidobacteria studied so far suggest that these bacteria are versatile heterotrophs with slow metabolic rates under low nutrient and low $\mathrm{pH}$ conditions, and can 
tolerate the fluctuation of soil moisture [31]. These bacteria may play an important ecological role by degrading polysaccharides (e.g., cellulose and chitin) of plant and fungal origin and they are key player in the C cycle [34].

\section{Conclusions}

Comparing the results of different approaches, twice as many phyla or classes were revealed by molecular cloning than cultivation, but the most abundant taxa, Proteobacteria, and Actinobacteria proved to be identical. The composition of soil bacterial communities seemed to depend on both geographic location and soil type as Rendzic Leptosol and Leptic Phaeozem samples from Tapolca karst were more similar to each other than Rendzic Leptosol and Leptic Luvisol samples from Aggtelek karst. The soil sample with the highest humus content was characterized by the lowest bacterial diversity values and Gram-positive dominance (Actinobacteria and Firmicutes). In contrast, the highest taxon diversity with high proportion of Acidobacteria was detected in the other soil sample with substantial clay content. In the soil bacterial communities of the Tapolca karst, Gammaproteobacteria occurred in high proportions, which could be in connection with the contamination of these sampling sites. To a better understanding of the relationships between geographic location, soil properties, bacterial community structures, and functioning, further examinations are needed.

\section{Funding Sources}

This research was supported by the Hungarian Scientific Research Fund (OTKA, grants no. T79135).

\section{Conflict of Interest}

Hereby, the authors declare no conflict of interest present.

\section{References}

1. Keveiné-Bárány, I.: Genetic types, human impacts, and protection of Hungarian karsts. Acta Climatologica Chorologica 38-39, 17-23 (2005).

2. Zhang, P., Li, L., Pan, G., Ren, J.: Soil quality changes in land degradation as indicated by soil chemical, biochemical and microbiological properties in a karst area of southwest Guizhou, China. Environ Geol 51, 609-619 (2006). 
3. Zhou, J. P., Huang, Y., Mo, M. H.: Phylogenetic analysis on the soil bacteria distributed in karst forest. Braz J Microbiol 40, 827-837 (2009).

4. Zhu, H., He, X., Wang, K., Su, Y., Wu, J.: Interactions of vegetation succession, soil bio-chemical properties and microbial communities in a karst ecosystem. Eur J Soil Biol 51, $1-7$ (2012).

5. Chen, X., Su, Y., He, X., Wei, Y., Wei, W., Wu, J.: Soil bacterial community composition and diversity respond to cultivation in karst ecosystems. World J Microbiol Biotechnol 28, 205-213 (2012).

6. Hu, N., Li, H., Tang, Z., Li, Z., Li, G., Jiang, Y., Hu, X., Lou, Y.: Community size, activity and $\mathrm{C}: \mathrm{N}$ stoichiometry of soil microorganisms following reforestation in a karst region. Eur J Soil Biol 73, 77-83 (2016).

7. Zhang, X., Liu, S., Li, X., Wang, J., Ding, Q., Wang, H., Tian, C., Yao, M., An, J., Huang, Y.: Changes of soil prokaryotic communities after clear-cutting in a karst forest: Evidences for cutting-based disturbance promoting deterministic processes. FEMS Microbiol Ecol 92, fiw026 (2016).

8. Zámbó, L.: The experimental examination of microbial origin corrosion aggressivity of karst soils. Acta Carsologica 16, 261-275 (1998).

9. Knáb, M., Szili-Kovács, T., Kiss, K., Palatinszky, M., Márialigeti, K., Móga, J., Borsodi, A. K.: Comparison of soil microbial communities from two distinct karst areas in Hungary. Acta Microbiol Immunol Hung 59, 91-105 (2012).

10. Janssen, P. H., Yates, P. S., Grinton, B. E., Taylor, P. M., Sait, M.: Improved culturability of soil bacteria and isolation in pure culture of novel members of the divisions Acidobacteria, Actinobacteria, Proteobacteria, and Verrucomicrobia. Appl Environ Microbiol 68, 2391-2396 (2002).

11. Cavaglieri, L., Orlando, J., Etcheverry, M.: Rhizosphere microbial community structure at different maize plant growth stages and root locations. Microbiol Res 164, 391-399 (2009).

12. Kumar, G., Kanaujia, N., Bafan, A.: Functional and phylogenetic diversity of root-associated bacteria of Ajuga bracteosa in Kangra valley. Microbiol Res 167, 220-225 (2012).

13. Shade, A., Hogan, C. S., Klimowicz, A. K., Linske, M., McManus, P. S., Handelsman, J.: Culturing captures members of the soil rare biosphere. Environ Microbiol 14, 2247-2252 (2012).

14. Quirino, B. F., Pappas, G. J., Tagliaferro, A. C., Collevatti, R. G., Neto, E. L., da Silva, M. R. S. S., Bustamante, M. M. C., Krüger, R. H.: Molecular phylogenetic diversity of bacteria associated with soil of the savanna-like Cerrado vegetation. Microbiol Res 164, 59-70 (2009).

15. Baldrian, P., Kolařík, M., Štursová, M., Kopecký, J., Valášková, V., Větrovský, T., Žifč́áková, L., Šnajdr, J., Rídl, J., Vlček, C., Vořrišsová, J.: Active and total microbial communities in forest soil are largely different and highly stratified during decomposition. ISME J 6, 248-258 (2012).

16. Hartmann, M., Howes, C. G., Van Insberghe, D., Yu, H., Bachar, D., Christen, R., Nilsson, R.H., Hallam, S.J., Mohn, W.W. Significant and persistent impact of timber harvesting on soil microbial communities in northern coniferous forests. ISME J $\mathbf{6}$, 2199-2218 (2012).

17. Dunbar, J., Takala, S., Barns, S. M., Davis, J. A., Kuske, C. R.: Levels of bacterial community diversity in four arid soils compared by cultivation and 16S rRNA gene cloning. Appl Environ Microbiol 65, 1662-1669 (1999). 
18. Felske, A., Wolterink, A., van Lis, R., de Vos, W. M., Akkermans, A. D.: Searching for predominant soil bacteria: 16S rDNA cloning versus strain cultivation. FEMS Microb Ecol 30, 137-145 (1999).

19. Ramírez-Saad, H. C., Sessitsch, A., Akkermans, A. D. L.: Molecular diversity in the bacterial community and the fluorescent pseudomonads group in natural and chlorobenzoate-stressed peat-forest soil. Microbiol Res 158, 47-54 (2003).

20. Van Insberghe, D., Hartmann, M., Stewart, G. R., Mohn, W. W.: Isolation of a substantial proportion of forest soil bacterial communities detected via pyrotag sequencing. Appl Environ Microbiol 79, 2096-2098 (2013).

21. Waksman, S. A.: The Actinomycetes I-II. Williams \& Wilkins Co., Baltimore, 1961.

22. Lane, D. J.: 16S/23S rRNA sequencing. In Stackebrandt, E., Goodfellow, M. (eds): Nucleic Acid Techniques in Bacterial Systematics. Wiley, New York, 1991, pp. 115-175.

23. Nübel, U., Engelen, B., Felske, A., Snaidr, J., Wieshuber, A., Amann, R. I., Ludwig, W., Backhaus, H.: Sequence heterogeneities of genes encoding 16S rRNAs in Paenibacillus polymyxa detected by temperature gradient gel electrophoresis. J Bacteriol 178, 5636-5643 (1996).

24. Sambrook, J., Russell, D. W.: Molecular Cloning. Cold Spring Harbor, NY: Cold Spring Harbor Laboratory Press, 2001.

25. Massol-Deya, A. A., Odelson, D. A., Hickey, R. F., Tiedje, J. M.: Bacterial community fingerprinting of amplified $16 \mathrm{~S}$ and $16 \mathrm{~S}-23 \mathrm{~S}$ ribosomal DNA gene sequences and restriction endonuclease analysis (ARDRA). In Akkermans, A. D. L., Van Elsas, J. D., De Bruijn, F. J. (eds): Molecular Microbial Ecology Manual 3.3.2, 1995, pp 289-296.

26. Altschul, S. F., Gish, W., Miller, W., Myers, E. W., Lipman, D. J.: Basic local alignment search tool. J Mol Biol 215, 403-410 (1990).

27. Kim, O. S., Cho, Y. J., Lee, K., Yoon, S. H., Kim, M., Na, H., Park, S. C., Jeon, Y. S., Lee, J. H., Yi, H., Won, S., Chun, J.: Introducing EzTaxon: A prokaryotic 16S rRNA gene sequence database with phylotypes that represent uncultured species. Int J Syst Evol Microbiol 62, 716-721 (2012).

28. Tamura, K., Peterson, D., Peterson, N., Stecher, G., Nei, M., Kumar, S.: MEGA5: Molecular evolutionary genetics analysis using maximum likelihood, evolutionary distance, and maximum parsimony methods. Mol Biol Evol 28, 2731-2739 (2011).

29. Shannon, C. E., Weaver, W.: The Mathematical Theory of Communication. University of Illinois Press, Urbana, 1949.

30. Hammer, R., Harper, D. A. T., Ryan, P. D.: PAST: Paleontological statistics software package for education and data analysis. Palaeontologia Electronica 4, 9 (2001).

31. Ward, N. L., Challacombe, J. F., Janssen, P. H., Henrissat, B., Coutinho, P. M., Wu, M., Xie, G., Haft, D. H., Sait, M., Badger, J., Barabote, R. D., Bradley, B., Brettin, T. S., Brinkac, L. M., Bruce, D., Creasy, T., Daugherty, S. C., Davidsen, T. M., DeBoy, R. T., Detter, J. C., Dodson, R. J., Durkin, A. S., Ganapathy, A., Gwinn-Giglio, M., Han, C. S., Khouri, H., Kiss, H., Kothari, S. P., Madupu, R., Nelson, K. E., Nelson, W. C., Paulsen, I., Penn, K., Ren, Q., Rosovitz, M. J., Selengut, J. D., Shrivastava, S., Sullivan, S. A., Tapia, R., Thompson, L. S., Watkins, K. L., Yang, Q., Yu, C., Zafar, N., Zhou, L., Kuske, C. R.: Three genomes from the phylum Acidobacteria provide insight into the lifestyles of these microorganisms in soils. Appl Environ Microbiol 75, 2046-2056 (2009).

32. Araujo, J. F., de Castro, A. P., Costa, M. M. C., Togawa, R. C., Júnior, G. J. P., Quirino, B. F., Bustamante, M. M. C., Williamson, L., Handelsman, J., Krüger, R. H.: Characterization 
of soil bacterial assemblies in Brazilian savanna-like vegetation reveals Acidobacteria dominance. Microb Ecol 64, 760-770 (2012).

33. Bachar, A., Soares, M. I. M., Gillor, O.: The effect of resource islands on abundance and diversity of bacteria in arid soils. Microb Ecol 63, 694-700 (2012).

34. Lladó, S., Žifčáková, L., Větrovský, T., Eichlerová, I., Baldrian, P.: Functional screening of abundant bacteria from acidic forest soil indicates the metabolic potential of Acidobacteria subdivision 1 for polysaccharide decomposition. Biol Fertil Soils 52, 251-260 (2016).

35. Elshahed, M. S., Youssef, N. H., Spain, A. M., Sheik, C., Najar, F. Z., Sukharnikov, L. O., Roe, B. A., Davis, J. P., Schloss, P. D., Bailey, V. L., Krumholz, L. R.: Novelty and uniqueness patterns of rare members of the soil biosphere. Appl Environ Microbiol 74, 5422-5428 (2008).

36. Upchurch, R., Chiu, C. Y., Everett, K., Dyszynski, G., Coleman, D. C., Whitman, W. B.: Differences in the composition and diversity of bacterial communities from agricultural and forest soils. Soil Biol Biochem 40, 1294-1305 (2008).

37. Jangid, K., Williams, M. A., Franzluebbers, A. J., Blair, J. M., Coleman, D. C., Whitman, W. B.: Development of soil microbial communities during tallgrass prairie restoration. Soil Biol Biochem 42, 302-312 (2012).

38. Jangid, K., Williams, M. A., Franzluebbers, A. J., Schmidt, T. M., Coleman, D. C., Whitman, W. B.: Land-use history has a stronger impact on soil microbial community composition than aboveground vegetation and soil properties. Soil Biol Biochem 43, 2184-2193 (2011).

39. Macalady, J. L., Jones, D. S., Lyon, E. H.: Extremely acidic, pendulous cave wall biofilms from the Frasassi cave system, Italy. Environ Microbiol 9, 1402-1414 (2007).

40. Alexandre, A., Brigido, C., Laranjo, M., Rodrigues, S., Oliveira, S.: Survey of Chickpea Rhizobia diversity in Portugal reveals the predominance of species distinct from Mesorhizobium ciceri and Mesorhizobium mediterraneum. Microb Ecol 58, 930-941 (2009).

41. Militon, C., Boucher, D., Vachelard, C., Perchet, G., Barra, V., Troquet, J., Peyretaillade, E., Peyret, P.: Bacterial community changes during bioremediation of aliphatic hydrocarbon-contaminated soil. FEMS Microbiol Ecol 74, 669-681 (2010).

42. Wust, P. K., Horn, M. A., Drake, H. L.: Clostridiaceae and Enterobacteriaceae as active fermenters in earthworm gut content. ISME J 5, 92-106 (2011).

43. Martin-Laurent, F., Phillipot, L., Hallet, S., Chaussod, R., Germon, J. C., Soulas, G., Catroux, G.: DNA extraction from soils: Old bias for new microbial diversity analysis methods. Appl Environ Microbiol 67, 2354-2359 (2001).

44. Elsas, J. D., Jansson, J. K., Trevors, J. T.: Modern Soil Microbiology, $2^{\text {nd }}$ Edition. CRC Press/Taylor \& Francis, Boca Raton, FL, 2007.

45. Lauro, M. F., McDougald, D., Thomas, T., Williams, T. J., Egan, S., Rice, S., DeMaere, M. Z.: The genomic basis of trophic strategy in marine bacteria. PNAS 106, 15527-15533 (2009).

46. Jakobi, K., Hertweck, C.: A gene cluster encoding resistomycin biosynthesis in Streptomyces resistomycificus; Exploring polyketide cyclization beyond linear and angucyclic patterns. J Am Chem Soc 126, 2298-2299 (2004).

47. Ueberschaar, N., Le Sage Tchize Ndejouong, B., Ding, L., Maier, A., Fiebig, H. H., Hertweck, C.: Hydrazidomycins, cytotoxic alkylhydrazides from Streptomyces atratus. Bioorg Med Chem Lett 21, 5839-5841 (2011). 
48. Li, H., Lin, Y., Guan, W., Chang, J., Xu, L., Guo, J., Wei, G.: Biosorption of Zn (II) by live and dead cells of Streptomyces ciscaucasicus strain CCNWHX 72-14. J Hazard Mater 179, 151-159 (2010).

49. Guo, J. K., Lin, Y. B., Zhao, M. L., Sun, R., Wang, T. T., Tang, M., Wei, G. H.: Streptomyces plumbiresistens sp. nov., a lead-resistant actinomycete isolated from lead-polluted soil in north-west China. Int J Syst Evol Microbiol 59, 1326-1330 (2009).

50. Xu, J. L., He, J., Wang, Z. C., Wang, K., Li, W. J., Tang, S. K., Li, S. P.: Rhodococcus qingshengii sp. nov., a carbendazim-degrading bacterium. Int J Syst Evol Microbiol 57, 2754-2757 (2007).

51. Groth, I., Vettermann, R., Schuetze, B., Schumann, P., Saiz-Jimenez, C.: Actinomycetes in Karstic caves of northern Spain (Altamira and Tito Bustillo). J Microb Methods 36, 115-122 (1999).

52. Jurado, V., Groth, I., Gonzalez, J. M., Laiz, L., Saiz-Jimenez, C.: Agromyces salentinus sp. nov. and Agromyces neolithicus sp. nov. Int J Syst Evol Microbiol 55, 153-157 (2005). 